Problemy Polityki Społecznej 2020, 50(3): 7-25

https://doi.org/10.31971/16401808.50.3.2020.1

Submitted: February 2020/Accepted: August 2020

Ulla Pape

ORCID: 0000-0001-8611-1665

Otto Suhr Institute of Political Science

Freie Universität Berlin ${ }^{1}$

\title{
Civil society development in Germany: challenges and opportunities
}

\begin{abstract}
This article provides a snapshot analysis of civil society development in Germany. Based on an online survey and in-depth-interviews with civil society experts, conducted in 2016, it studies the challenges and opportunities experienced by German civil society organizations (CSOs). The article highlights the perceptions of the context conditions of civil society development and analyses the organisational responses which CSOs have adopted in response to a changes in their societal and political environment. The study argues that German CSOs have mainly experienced difficulties with fundraising and project organization, including problems with adhering to increasingly bureaucratic funding regulations. Among societal and political challenges, CSO representatives mentioned societal cleavages and stressed the role of CSOs in fostering integration and building bridges among diverse groups of society. Three organizational case studies illustrate how CSOs have managed to deal with changes in their environment. Although German CSOs have been experiencing challenges, they described the context conditions as relatively stable and favourable. From a theoretical perspective, the study contributes
\end{abstract}

1 Correspondence: Dr. Ulla Pape, Otto Suhr Institute of Political Science, Freie Universität Berlin, Ihnestraße 21, 14195 Berlin, Bundesrepublik Deutschland, author's email address: ulla.pape@fu-berlin.de. 
to the discussion on the "shrinking spaces for civil society", as it shows that CSOs are adaptable and can develop despite external challenges.

Key words: civil society, Germany, challenges, opportunities, social cohesion

\section{Introduction}

This article investigates the challenges and opportunities in civil society development in Germany. It presents the findings of an online survey and an interview study among civil society representatives, which was conducted as part of the "Report on the State of Civil Society in the EU and Russia" of the EU-Russia Civil Society Forum in 2016. ${ }^{2}$ The article aims to highlight the perceptions of civil society representatives about the context conditions of civil society development in Germany and analyses the organisational responses which civil society organisations (CSOs) have adopted in response to a changes in their societal and political environment.

The trends for civil society development in Germany are of particular importance. First, the German case shows an example of a developed democracy and social market economy, where civil society has always played a very important role in the implementation of welfare. Second, the experiences of migration and particularly the refugee crisis in 2015 have spiked some interesting development of civic activism in Germany. The findings of the German case study can thus contribute to a better understanding of general trends and be interesting for a broader academic readership across Europe.

Two research questions are central to the investigation: what have been the main challenges for CSOs in Germany, and how have organisations responded by developing organisational solutions and so-called best practices? The article is structured as follows: first, the background of the research project is explained and a brief overview of civil society development, legal regulations, organisational forms and funding resources in Germany is provided. Second, the analytical framework is introduced and the main terms - challenges, opportunities and best practices — are defined. Third, the data sources and the methodological approach of the study are explained. The following part is the presentation of the research findings which includes (1) information on the surveyed organisations, (2) overview of the challenges experienced by civil society representatives, (3) main challenges of civil society, (4) main opportunities of civil society, and (5) case studies of best practices. The article is concluded by a discussion and conclusion which places the findings in a broader context.

22016 Report on the State of Civil Society in the EU and Russia, available at https:/eu-russiacsf.org/project/report-2016/ (accessed: 28.09.2020). The collaborative research project was conducted under the scientific leadership of Elena Belokurova. 


\section{Background: monitoring civil society development in Europe}

This article emerged from a collaborative research endeavour undertaken by the EU-Russia Civil Society Forum, a network of more than 150 civil society organisations (CSOs) in the countries of the European Union and Russia. ${ }^{3}$ In 2016, the member organisations of the forum initiated a research project on the state of civil society in the EU and Russia to gather and exchange information on the changing situation of CSOs in Europe and Russia. A specific objective of the project is to better understand the so-called "shrinking space for civil society" (Anheier et al., 2019). The project members therefore aimed at identifying challenges and opportunities for CSOs in the different countries in Europe and Russia.

Challenges are understood as legal, political or societal developments that have an impact on civil society in Europe. Opportunities include the responses European CSOs have developed in order to deal with the changing context conditions. Some of the solutions individual organisations have invented can be of use for CSOs in other policy fields or countries. The report is therefore also aimed at contributing to civil society advocacy. By gathering and exchanging information on challenges and opportunities that project members strive to evaluate the achievements of CSOs and strengthen their self-awareness and impact. Since 2016, the "Report on the State of Civil Society in the EU and Russia" has been appearing on an annual basis. The authors of the country chapters are civil society experts in different parts of Europe with experience in both research and community engagement. The collaborative work on the reports has brought together a valuable body of information on civil society development in the countries of the European Union and Russia.

\section{German Civil Society at a Glance}

CSOs have a long tradition in Germany, particularly in the fields of welfare, education, sports and culture. Many organisations can trace their history back to the $19^{\text {th }}$ century; others were founded in the first decades after the $2^{\text {nd }}$ World War. Among the organisations, which took part in this study, a clear majority (nearly 70 percent; 36 out of 52 CSOs) existed for more than 20 years.

A characteristic of the German welfare system is the close cooperation with social sector organisations, the so-called Verbände (Zimmer, 2010). This welfare system is described as a "corporate welfare system", in which state institutions work in close partnerships with civil society, also called "welfare partnerships" (Archambault et al., 2014). Social services are provided by a network of umbrella organisations that have local branches and implementing partners. Social umbrella organisations, e.g. Caritas, AWO and Kolpingwerk, play an important role in providing social services (Zimmer, 2010). These organisations are also important in the advocacy work with regard to their members and beneficiaries.

3 More information about the EU-Russia Civil Society Forum can be found on its website: https://eu-russia-csf.org/ (accessed: 21 November 2020). 
These partnership mechanisms mean that many CSOs have stable cooperation and funding agreements with state institutions, such as ministries and specialized government agencies.

German civil society also receives support from political decision-makers for offering opportunities for voluntary service which is considered an important element for social cohesion and therefore considered as a societal task (Enquete-Kommission, 2002; Olk et al., 2010). Voluntary service is essential for civil society development in Germany. In 2014, more than 30 million people of 14 years or older had experience with volunteering in CSOs which equals 40 percent of the population (Simonson et al., 2017; see also Deutscher Freiwilligensurvey FWS).

There are different legal forms of civil society organisations in Germany: one distinguishes between associations (Vereine), umbrella organisations (Verbände) and foundations (Stiftungen). The largest part of CSOs in Germany are associations (Vereine). There are almost 600,000 associations registered (Zimmer et al. 2016; see also Zivilgesellschaft in Zahlen). The majority of these associations are small and are active at the local level (Zimmer et al., 2016). The density of associations is equally spread over the different federate states (Länder) (Zimmer et al., 2016).

Next to associations, foundations have become very popular in Germany over the past years. Legal reforms gave rise to a so-called foundation boom between 2002 and 2007. According to the Association of German Foundations, there are currently around 21,000 private foundations operating in Germany (Zimmer et al., 2016; see also Zivilgesellschaft in Zahlen). Most likely, the total number of foundations is even higher, as public registration offices are not obliged to make their date files accessible (Zimmer et al., 2016). Tax-exempt co-operatives have regained popularity after the EU has lightened the requirements to start a co-operative. The overall number of cooperatives in Germany, however, is only around 900 (Zimmer et al., 2013, p. 27; Zimmer et al., 2016). Tax exempted co-operatives are increasingly to be found in the areas of renewable energy and shared housing for senior citizens (Zimmer et al., 2016).

Typically, CSOs in Germany rely on a mix of funding resources (Priemer et al., 2015). However, there is a traditional division between organisations being active in the welfare domain (social services and health care), which are primarily financed through social and health insurance allowances and are thus incorporated in the German welfare state system (Zimmer \& Priller, 2007, p. 81), and CSOs in other policy fields (such as sports or arts and culture) which rely on membership fees and private donations.

The general legal framework for CSOs in Germany has been described as favourable and stable. The most common organisational and legal forms that are linked to civil society in Germany are associations (Verein), cooperatives (Genossenschaften), and private law foundations (Stiftung des Privatrechts). These organisational and legal forms date back to the time of the German Empire (Zimmer et al., 2016). The different organisational forms follow different organisational rationales (Zimmer et al., 2016). Associations are established on the concept of reciprocity, whereby activities are organized for members by members (Zimmer et al., 2016). Co-operatives are meant to minimize economic risks 
to their members and allow them to access markets of goods and services or financial products (Zimmer et al., 2016). Foundations are organisations that are not member-based and non-commercial (Zimmer et al., 2016). They relate to civil society, as they might provide finances for charitable causes.

Recently a new form legal form - the private limited company (gemeinnützige Unternehmergesellschaft, UG) was introduced in Germany in order in order to facilitate start-ups of social enterprises (Zimmer et al., 2016). The rationale for introducing a new legal form is that social enterprises have a charitable purpose, but - in contrast to associations - need to operate in the market. This new legal form, however, has not yet gained significant importance (Zimmer et al., 2016).

\section{Understanding civil society challenges and opportunities}

This article focuses on challenges and opportunities for civil society in Germany. The research design is of explorative nature. Its objective is to understand how civil society representative have perceived the current changes that have affected their organisations and how they understand the opportunities for civil society development. As analytical lens, the article draws upon the concept of "shrinking space for civil society" (Hummel, 2019) which refers to changes in the political context that have an impact on the organisational space of civil society. The analysis of current trends in civil society development in Germany includes both organisational challenges and opportunities.

Challenges are defined as changes in the context conditions which affect the work of CSOs. They relate to the legal framework, public financing, private donations, public opinion, state support, volunteering and media coverage (see also: Evers \& Zimmer, 2010). Opportunities refer to organisational responses to the changing context conditions which enable the organisations to adapt and to flourish. Similar to challenges, opportunities can relate to different aspects of organisational development, including funding, project management, communication and public relations. Opportunities include so-called "best practices", which are defined as organisational solutions of individual CSOs that are transferable to other organisations.

The investigation of challenges and opportunities proceeds in three steps. First, we investigated what civil society representatives in Germany identified as important challenges to their organisations. Second, we identified the main opportunities and best practices reported by civil society representatives in Germany.

\section{Study on civil society in Germany: data and methodology}

The data for this study was collected in the framework of the research project on the "State of Civil Society in the EU and Russia" in 2016. The research methodology is based on an online survey and interviews with representatives of CSOs in Germany.

The online survey was conducted from mid-July to mid-September 2016. Parallel to Germany, four other research studies with the same methodology were conducted 
in Spain, Poland, Hungary and Russia. The findings of all five country case studies were later summarized in the 2016 "Report of the State of Civil Society in the EU and Russia". Regarding the online survey, a general questionnaire was developed in English, translated into all country languages and distributed via the software Qualtrics. Invitations to participate in the survey were sent to the personal e-mail addresses of CSO representatives in all participating countries. In addition, open invitations for the survey were distributed through relevant mailing lists and personal contacts in the respective countries. In Germany, the websites of Bundesnetzwerk Bürgerschaftliches Engagement, Initiative Transparente Zivilgesellschaft und Wegweiser Bürgergesellschaft were consulted for contacting CSOs. Furthermore, several announcements were made on the EU-Russia Civil Society Forum website.

Overall, 692 personal invitations were sent out and 75 completed responses were collected from 14 July to 16 September 2016. The online questionnaire included questions on the organisations' structure, size, years of experience, funding sources as well as perceived challenges and opportunities for organisational development.

In addition to the online survey, four in-depth interviews were conducted with civil society representatives in Germany who had expressed their interest in providing information. Each interview took about 40 to 60 minutes and covered the following topics: (1.) Challenges to CSOs in Germany in general, (2.) Challenges to the specific organisations, and (3.) Best practices developed by the organisation. The interviews were conducted via Skype, recorded as voice documents and consequently transcribed and analysed.

The survey respondents and interviewees included civil society experts and representatives of different forms of CSOs in Germany, who responded to the invitations, distributed via different relevant mailing lists. We included both non-governmental and non-profit organisations, informal initiatives, and social movements. Because we aimed to cover different kinds of civil society structures, we use the term of civil society organisations (CSOs), which is the broadest notion of civic activities. The majority of organisations which participated in the study, however, identify as non-profit organisations (NPOs).

\section{Findings}

In this section the finding of research study on civil society development in Germany are presented. The data on challenges and opportunities is first presented and then discussed.

\section{Information on the surveyed CSOs}

In Table 1, the fields of activity of the CSOs are presented, based on the answers to the questions of the online survey. This breakdown does not reveal the relation of organisations within civil society in Germany. It rather shows which organisations were more likely to respond to the online survey of the EU-Russia Civil Society Forum. Respondents came from different policy fields. Interestingly, more than one third of the 
respondents were active in organisations in the field of youth and education. This can be attributed to the fact that many youth organisations are active in international youth exchange programmes, which also include the collaboration with partner organisations in Eastern Europe and Russia. These organisations are more likely to respond to a call that focuses on civil society relations between the EU and Russia.

Table 1. Field of activity of the surveyed CSOs

\begin{tabular}{|l|c|c|}
\hline \multicolumn{1}{|c|}{ Field of activity } & Number of answers & Percentage \\
\hline Human rights & 9 & $17.3 \%$ \\
\hline Environmental protection & 2 & $3.9 \%$ \\
\hline Social policy & 2 & $3.9 \%$ \\
\hline Youth and Education & 19 & $36.5 \%$ \\
\hline History and Culture & 6 & $11.5 \%$ \\
\hline Sport and Leisure & 0 & $0.0 \%$ \\
\hline Other field & 14 & $26.9 \%$ \\
\hline$\# \mathrm{n}$ & 52 & $100.0 \%$ \\
\hline
\end{tabular}

Table 2 presents the data about the years of work experience in the CSOs. More than two thirds of respondents said to be engaged with an organisation that is older than 20 years. Only one respondent mentioned to be a representative of a newly founded CSO. This overview does not necessarily reflect the relations within German civil society. However, the table indicates that most CSOs in Germany are organisations with a relatively long history.

Table 2. Years of experience of the surveyed CSOs

\begin{tabular}{|l|c|c|}
\hline \multicolumn{1}{|c|}{ Answer option } & Number of answers & Percentages \\
\hline Less than one year & 1 & $1.9 \%$ \\
\hline $1-5$ years & 3 & $5.8 \%$ \\
\hline 6-10 years & 2 & $3.9 \%$ \\
\hline $10-20$ years & 10 & $19.2 \%$ \\
\hline More than 20 years & 36 & $69.2 \%$ \\
\hline \#n & 52 & $100.0 \%$ \\
\hline
\end{tabular}

Table 3 shows the number of active members in the organisation. More than one third of the respondents $(37.7 \%)$ are active in medium-size organisations with a number of 10 to 50 active members. One quarter of the respondents $(25.5 \%)$ is active for large organisations with more than 200 active people. 
Table 3. Number of people (employers, volunteers, and members) involved into the CSO in the year 2016

\begin{tabular}{|l|c|c|}
\hline \multicolumn{1}{|c|}{ Answer option } & Number of answers & Percentages \\
\hline Less than 10 people & 10 & $19.6 \%$ \\
\hline $10-50$ people & 19 & $37.7 \%$ \\
\hline $50-100$ people & 7 & $13.7 \%$ \\
\hline $100-200$ people & 2 & $3.9 \%$ \\
\hline More than 200 people & 13 & $25.5 \%$ \\
\hline$\# \mathrm{n}$ & 51 & $100.0 \%$ \\
\hline
\end{tabular}

Table 4 shows the policy level at which the organisation is predominantly active. In this question more than one answer was possible. More than half of the organisations $(56.9 \%)$ are active at the national level (29 out of 51 CSOs). More than two thirds of the organisations (66.7\%) are active at the international level (34 out of 51 CSOs). The international level includes cooperation ties with partner organisations in other countries.

Table 4. Policy level (more than one answer possible)

\begin{tabular}{|l|c|c|}
\hline \multicolumn{1}{|c|}{ Answer option } & Number of answers & Percentages \\
\hline Only in the capital & 3 & $5.9 \%$ \\
\hline In other cities/towns & 4 & $7.8 \%$ \\
\hline At the local level & 14 & $27.5 \%$ \\
\hline At the regional level & 18 & $35.3 \%$ \\
\hline At the level of one state (Bundesland) & 15 & $29.4 \%$ \\
\hline At the national level & 29 & $56.9 \%$ \\
\hline At the international level & 34 & $66.7 \%$ \\
\hline$\# \mathrm{n}$ & 51 & - \\
\hline
\end{tabular}

\section{Overview of challenges experienced by civil society representatives}

The challenges of CSOs are presented here are based on the analysis of the respondents' answers in the online survey. The first question concerns the general evaluation of the current situation.

From the answers to question 1, we can conclude that more than $60 \%$ of the respondents (45 out of 72 CSOs) assessed the situation of their organisation as stable or improving. Only $22 \%$ of the respondents observed a deterioration of their organisation's overall situation over the past year. $15 \%$ of the respondents found it difficult to answer the question. 
Table 5. Question 1: How has the situation of your organisation changed over the past three years (2013-2016)? (only one answer possible)

\begin{tabular}{|l|c|c|}
\hline \multicolumn{1}{|c|}{ Answer option } & Number of answers & Percentage \\
\hline The situation of my organisation has improved. & 18 & $25.0 \%$ \\
\hline The situation of my organisation has deteriorated. & 16 & $22.2 \%$ \\
\hline The situation of my organisation stayed the same. & 27 & $37.5 \%$ \\
\hline Difficult to say / no answer & 11 & $15.3 \%$ \\
\hline$\# \mathrm{n}$ & 72 & $100.0 \%$ \\
\hline
\end{tabular}

Table 6. Question 2: How do you evaluate the context conditions for your NGOs with regard to legal framework, financing, private donations, public opinion, state support, volunteering and media coverage?

\begin{tabular}{|l|c|c|c|c|c|c|}
\hline \multicolumn{1}{|c|}{ Field } & $\begin{array}{c}\text { Very } \\
\text { negative }\end{array}$ & Negative & Neutral & Positive & $\begin{array}{c}\text { Very } \\
\text { positive }\end{array}$ & \#n \\
\hline State funding & 7 & 6 & 26 & 28 & 5 & 72 \\
\hline Private donations & 8 & 18 & 25 & 18 & 2 & 71 \\
\hline Public opinion & 1 & 10 & 17 & 38 & 7 & 73 \\
\hline State support and legal situation & 4 & 7 & 15 & 40 & 6 & 72 \\
\hline Voluntary participation & 4 & 5 & 17 & 32 & 13 & 71 \\
\hline Media reporting & 10 & 9 & 29 & 22 & 2 & 72 \\
\hline
\end{tabular}

The answers to question 2 show a similar picture than those to question 1 . A majority of respondents described the context conditions of their organisation as "positive". Particularly state funding and state support and the legal situation are assessed in positive way: 33 out of 72 describe state funding as positive or very positive. The respondents were the least positive about private donations; here the number of respondents who assess the context conditions as "negative" equals the number of respondents who assess the context conditions as "positive". With regard to public opinion and voluntary participation, a majority of respondents was satisfied with the context conditions. Media reporting forms an interesting issue. Most respondents evaluated the situation as 'neutral' or 'positive'. However, there is also a significant number of respondents who assessed media reporting to be 'negative' or even 'very negative'. This indicates that media reporting forms a concern to those groups and organisations in Germany that are working on topical issues, including the political relations with Russia and Eastern Europe, the response to the refugee crisis in Europe and human rights issues.

Overall, we can conclude that most CSO representatives in Germany assess the context conditions for civil society development as favourable. In general, CSOs appeared to be satisfied with the legal situation and with state support programmes. They also described 
public opinion as positive towards civil society. Voluntary participation was also described as predominantly positive. There were some concerns with the levels of private donations and media reporting. Overall, CSO representatives perceived the context for civil society development in Germany as favourable and stable.

Table 7. Question 3: What kind of major challenges have civil society organisations faced in your country over the last year (open question)?

\begin{tabular}{|l|}
\hline \multicolumn{1}{|c|}{ Summary of open answers - challenges to CSOs in Germany } \\
\hline $\begin{array}{l}\text { Financial challenges: Decrease in funding / Short term project financing / decrease in private dona- } \\
\text { tions, problems with long-term financing, funding for employees, co-funding makes the financing } \\
\text { of projects difficult, lack of financing for ongoing work and overhead, problems with structural } \\
\text { funding, 'project-hopping' }\end{array}$ \\
\hline $\begin{array}{l}\text { Problems in cooperation with CSOs in Russia: War in Ukraine / humanitarian situation / vulner- } \\
\text { able population, law on foreign agents in Russia, authoritarian rule in Russia, repression of NGOs } \\
\text { in Russia, cooperation with Russian NGOs become more difficult }\end{array}$ \\
\hline $\begin{array}{l}\text { Organisational challenges: young people have less time for voluntary work, recruitment of volun- } \\
\text { teers, employees are overburdened, risk of burn-out, difficulties to find voluntary board members, } \\
\text { competition among NGOs }\end{array}$ \\
\hline Political problems: integration, refugee crisis, radicalization in society, migration \\
\hline Legal challenges: strict regulations for associations \\
\hline $\begin{array}{l}\text { Media: difficulties to get media attention, negative media reporting, communication challenges: } \\
\text { NGOs need to present themselves in social media }\end{array}$ \\
\hline Societal challenges: racism, xenophobia \\
\hline
\end{tabular}

This question was answered by 46 respondents.

From the open answer to the third question we can conclude that CSO representatives perceived financial challenges to be most relevant. Many respondents described a decrease in structural funding and a growing dependence on project financing as a major concern for civil society. CSO representatives described that these shifts in funding arrangements have made organisational development more challenging. Internal challenges such as high workload form a second concern for CSOs in Germany. Due to increasing challenges to the organisations, the performance requirements for people employed in CSOs have grown. Some organisations reported about problems with workload and time pressure.

With regard to public opinion, some organisations described the current situation as more challenging than in the past. New channels of communication also mean that CSOs have to strengthen their communication skills, e.g. in presenting themselves in social media and on the internet, a recent trend which is also described by Koch-Baumgarten (2014). For some organisations these new requirements form a concern, as time and personnel resources are limited. 
Political and societal changes constitute a third area of challenges for civil society organisations in Germany. Some organisations mentioned migration and in particular the refugee crisis in 2015/2016 as a new challenge for civil society. However, some organisations saw integration also as a new chance for civil society. Other societal developments that were described as problematic included political radicalization and growing xenophobia. CSOs working with partners in Eastern Europe mentioned the tensions between Europe and Russia, the repressions against civil society in Russia and the War in Ukraine as a growing concern. Due to these political tensions, cooperation with partner organisations in Russia and other countries in Eastern Europe has become more challenging, as CSOs felt that they need to protect their partner organisations.

Table 8. Question 4: What kind of challenges has your organisation faced over the last year (open question)?

\section{Summary - challenges to the specific organisation}

Financial challenges: short-term project financing, decrease in funding and private donations, financial sustainability is under threat, financing

Organisational challenges: bureaucratic requirements increased, finding qualified staff members Cooperation: difficulties in registering funding through Belarussian partner organisations

Political challenges: War in Ukraine, cooperation with Russian NGOs become difficult, more support from official decision-makers is needed for voluntary work, political tensions in Eastern Europe, Putin's policies, refugee crisis, difficulty to finance programs with Russian partners, difficulty to keep contact with Russian partners

Societal challenges: new societal developments are a challenge to the organisation, readiness to work in an intercultural society

Voluntary engagement: difficulties in activating young people

Information: difficulty to inform about Russia in Germany

Media: strong competition regarding media reporting and attention among CSOs

This question was answered by 41 respondents.

Question 4 asked about the specific challenges the organisations have been facing over the past year. The answers to this question for a great deal overlap with the answers to question 3. This shows that most respondents did not see a major difference between the development of their organisation and civil society in general.

The challenges that were described most often include financial and organisational challenges. For many CSOs in Germany, it has become more difficult to raise funding for programme development. In many areas, structural funding has been replaced by short-term project funding which makes organisational development more challenging and in some cases impedes the sustainability of CSOs.

With regard to media reporting, CSO representatives reported a growing competition among organisation over media attention. It is important for CSOs to be present in the 
media in order to voice their messages and raise public support. As there are many organisations with different objectives, the competition over media reporting has been increasing.

Organisations that work together with Russian partners reported increasing problems in their cooperation. Due to the growing political tensions between Europe and Russia following the annexation of Crimea in 2014, it has become more challenging to report about Russia in an objective way in Germany. CSO representatives report that public opinion towards Russia has become more adverse which also influences the work of CSOs.

\section{Main challenges for civil society in Germany}

On the basis of both the online survey and the interviews, a number of challenges that civil society organisations are facing in Germany can be identified. These challenges range from financial challenges to organisational, societal and political challenges.

Firstly, let us give an overview of the financial difficulties that CSOs experience in Germany. In the interviews, civil society representatives reported about financial difficulties. Financing was also the topic that was most often mentioned in the online survey. Fundraising is a concern for many CSOs in Germany. Many organisations depend on short-term project funding. With this type of funding, organisations find it difficult to cover their expenses for personnel costs and to invest in long-term organisational development. Often, project funding covers only a period of six months or one year. Organisations can thus not plan ahead, but have to work 'from project to project'. This trend towards short-term funding makes organisational development more challenging. In some cases, CSOs explained that they find it difficult to sustain their operations. In addition, CSOs mentioned that fundraising is very intense in terms of time, costs and personnel. In order to win a grant, CSOs have to invest a lot of energy, while at the same time having no security that their investment will play out for the organisation. Many CSOs therefore lack the resources for long-term planning for their organisation.

Secondly, many German CSOs have experienced organisational challenges. They faced difficulties with administrative requirements and an increasing bureaucratic pressure. Some organisations mentioned difficulties to find qualified staff members. For many organisations it is difficult to recruit volunteers, as volunteering has become more fluid and project-driven. Volunteers have become less committed to a specific organisation and more interested in supporting various charitable causes in a more flexible way.

Thirdly, CSOs in Germany reported societal challenges. Many respondents referred to general societal developments, which have an impact on civil society. Some interviewees mentioned demographic chance and immigration as major challenges for CSOs in Germany. Whereas in the past German society has been rather homogenous, it has become rather diverse. This has an impact on civil society. Organisations need to adjust to new intercultural conditions. Some organisations reported that they strive to open themselves to "new citizens". These organisations are of the opinion that civil society can play an important role in integration. 
Fourthly, CSOs in Germany experienced political challenges. Many respondents referred to the refugee crisis of 2015 as a challenge for CSOs. CSOs that are active in intercultural relations with Eastern Europe mentioned the Ukraine conflict, the political development in Russia and the tightening relations between Russia and Europe as a challenge to their transnational work. CSOs that closely cooperate with Russian or other European partners mentioned the political situation as a major stumbling obstacle. The organisations reported that cooperation with Russian partners has become a touchy issue, as organisations in Russia have been facing repression from the side of government agencies. Russian CSOs have experienced the effect of the so-called 'foreign agents' law and other repressive state regulation regarding non-profit organisations.

\section{Main opportunities for civil society in Germany}

Both the online survey and the in-depth interviews asked about opportunities for civil society in Germany. Opportunities were understood as organisational responses to the changing environment that enabled CSOs to adapt and to flourish amidst difficulties. In the survey, question 5 was dedicated to opportunities.

Table 9. Question 5: Has your organisation found some interesting solutions / best practices for the given challenges? Briefly describe. (Under "best practices", we mean innovative solutions, practices, initiatives, which allow civil society organisations to face and react to challenges.) (open question)

\begin{tabular}{|l|}
\hline \multicolumn{1}{|c|}{ Summary - best practices } \\
\hline $\begin{array}{l}\text { Human rights NGOs: forming a bridge between migrants and state institutions by using digital } \\
\text { communication means, focusing on young people and digital communication, more attention } \\
\text { for motivated members, broad focus of the NGOs (using all different means of nonprofit work) }\end{array}$ \\
\hline $\begin{array}{l}\text { Environmental NGOs: exchange and agreements with other NGOs, social entrepreneurship as an } \\
\text { opportunity for organisational development }\end{array}$ \\
\hline $\begin{array}{l}\text { Youth organisations: focus on marketing strategies, cooperation with universities, organisation of } \\
\text { information meeting at universities, recruitment of volunteers, looking for new forms of participa- } \\
\text { tion, accompanying programs by researchers, intercultural dialogue, opening of the organisation } \\
\text { towards 'new citizens', cooperation with other NGOs and with social entrepreneurs }\end{array}$ \\
\hline $\begin{array}{l}\text { Historical and cultural NGOs: continuation of cooperation under different name, if partner organ- } \\
\text { isation in Russia face legal problems, sponsorship for partner organisations, investing more money } \\
\text { in public relations and communications }\end{array}$ \\
\hline $\begin{array}{l}\text { NGOs in other fields: the so-called 'Ehrenamtmesse' (English: Fair on voluntary work) to pro- } \\
\text { mote voluntary work, support projects for refugees, focus on online communication, focus on } \\
\text { financial planning and control with the aim to meet bureaucratic requirements, participation of } \\
\text { volunteers in project planning and fundraising, public discourse on voluntary engagement, focus } \\
\text { on local projects }\end{array}$ \\
\hline
\end{tabular}

This question was answered by 49 respondents: 19 respondents expressed their interest in describing their organisation's best practices, 30 respondents answered with a "no". Based on the answered of the respondents and the in-depth interviews with CSO representatives we established the following summary of 'best practices' for the case study Germany. 
Depending on the sphere of activity, the presented examples of best practices vary across respondents. Interestingly, many CSO representatives described new forms of inter-organisational cooperation as a viable best practice. Other CSO representatives mentioned innovative programme activities, e.g. new forms of volunteering or integration projects as best practices of their organisation.

Communication forms a specific field of organisational innovation. Many CSO representatives mentioned that they have developed new marketing and public relations strategies to improve their communication with their members and supporters and to strengthen public support for the organisations.

CSOs that cooperate with Russian partners reported strategies to make cooperation with the partners more informal and less visible in order to protect and not harm the Russian partner organisations.

\section{Case Studies of Best Practices}

At the end of the questionnaire, the respondents were asked whether they were interested in giving an interview to share their best practices with other civil society organisations in other countries. This question was answered by 49 respondents; 19 respondents answered with "yes" (38.8\%), 30 respondents answered with 'no' $(61.2 \%)$. Respondents who had answered with "yes", were asked to provide their contact details. They were contacted, and as result, 4 interviews were conducted. As result of both the interviews and the online survey, the following "best practices" can be presented, which can serve as illustrations of how German CSOs have responded to ongoing changes in their environment.

\section{a. Inclusion and integration project at the German Youth Fire Service}

The German Youth Fire Service (Deutsche Jugendfeuerwehr) was founded in Berlin in 1964 as the youth organisation of the German Fire Service Federation (Deutscher Feuerwehrverband - DFV). ${ }^{4}$ However, the first youth fire brigades existed already many decades before. The first group was established in 1885 on the Frisian island Föhr. The German Youth Fire Service is a non-profit youth organisation with a public benefit status. It has 245,000 members aged between 10 and 18 years who are organized in 18.100 youth fire brigades throughout Germany. The organisation is present in almost every community, town and country in both East and West Germany.

In many local communities, the German Youth Fire Service plays an important role in education. Young people (10 to 18 years) can join a local fire brigade and train as voluntary fighters. In the course of this voluntary training, the participants acquire social and technical skills that prepare them for professional training and job life. An important element of the German Youth Fire Service is the culture of solidarity and mutual support.

${ }^{4}$ Deutsche Jugendfeuerwehr, available at https://jugendfeuerwehr.de/ (accessed: 18 September 2020). 
Members help each other beyond their voluntary work. In many communities, the fire services play an important role in social life.

Because of its role as a community organisation, the German Youth Fire Service has acknowledged its role in strengthening societal integration. The organisation has adopted several programmes that emphasize cultural diversity within the fire brigades. One campaign is called "Our world is colourful". With these activities, the organisation aims to attract new members with different cultural backgrounds. In addition, the German Youth Fire Service has stimulated the role of its organisation in the German democratic system. It aims to create a 'welcome culture' to new members of society. These intentions do not remain words on paper, but are realized in many local projects. Local branches, for instance, have debated on how they can adjust the traditional German barbecue evenings for members with different cultural eating habits (Interview 4 Berlin, 27 July 2016). By looking for practical solutions, the German Youth Fire Service has managed to create more diversity in the organisation. According to a representative of the German Youth Fire Service, "the strength of the organisation is its pragmatism" (Interview 4, Berlin, 27 July 2016). The organisation has therefore successfully adapted to the challenges of a changing society.

These organisational innovations show that the German Youth Fire Service has adapted to new societal trends, most importantly by adjusting to a multicultural environment and by emphasizing its role in a democratic society. By doing this, the organisation has contributed to the integration of newcomers in German society. Integration projects, such as those organized by the German Youth Fire Service, play a particularly important role for young people with a migration background. By becoming active in civil society, newcomers can obtain skills and knowledge which can become important for their work and societal integration. However, integration projects do not only fulfil a function for new members of society, but enable all participants to develop their intercultural skills. Similarly to the voluntary fire brigades in general, the German Youth Fire Service is particularly strong in rural areas in Germany. By organizing youth projects, the organisation strengthens social cohesion. It thereby plays an important cultural and societal role and contributes to life quality on the country side.

\section{b. An information blog on Ukraine and Russia by the Society for Threatened Peoples}

An organisational solution in the field of communication was developed by The Society for Threatened Peoples (Gesellschaft für bedrohte Völker), based in Göttingen and Berlin. ${ }^{5}$ The Society for Threatened Peoples (STP) is an international human rights organisation that advocates for threatened ethnic and religious minorities, nationalities and indigenous communities.

5 Society for Threatened Peoples (Gesellschaft für bedrohte Völker), https://gfbv.de/ (accessed: 3 October 2020). 
As a response to the violent conflict in Eastern Ukraine, The Society for Threatened Peoples developed a news blog 'Ukraine/Russia: Chronic of Current Affairs' . ${ }^{6}$ With this new information service, the organisation aims to provide impartial information on the human rights situation in the areas of Eastern Ukraine, affected by the violent conflict. With the new information tool, the organisation also strives to strengthen its position as information provider and reach out to the public (Interview 3, Berlin, 27 July 2016).

This example shows how CSOs can use information technology to develop their programmatic work. The Society for Threatened Peoples had already published reports and other information material, about the situation in Eastern Europe with a specific focus on small nations and interethnic relations, among others. As a response to the violent conflict in Eastern Ukraine, the organisation decided to develop a news blog to inform about the current development in the war zone. The news blog was used as a communication tool for providing first-hand information which is not available in mainstream media. The news blog also allowed the organisation to increase its support base.

Next to providing information about the human rights situation in Ukraine and Russia, The Society for Threatened Peoples also aimed to work towards intercultural understanding. According to a representative of the organisation, a peaceful dialogue between Russian and Ukrainian civil society organisations is needed to overcome the growing tensions and lack of understanding between the two societies (Interview 3, Berlin, 27 July 2016). CSOs in Germany strive to inform about the conflict and be in contact with organisations from both sides. To foster a peaceful dialogue is an idea that the organisation wants to realize with its information and communication activities (Interview 3, Berlin, 27 July 2016). The examples shows that organisational response, or 'best practices', often address more than one dimension of the organisation. The news blog is both a communication tool for the German audience, a mean to increase public support and a project for strengthening intercultural understanding.

\section{c. Support to refugees / Quarteera, Berlin}

Another communication activity was developed by the Berlin-based LGTBQ+ organisation Quarteera, which organizes support activities for migrants who have fled their home country because of repression with regard to their sexual orientation and their activities in LGTBQ+ organisations in their home country. With practical support, Quarteera seeks to assist in the communication with migrants and asylum seekers on the one hand and German state institutions on the other hand. The main programme activities of the CSO are community building, support and social work. In the social sphere, communication has gained increased relevance. Because of this, Quarteera has developed a blog, on which it informs about its activities in a blog. ${ }^{7}$ With the blog, the

${ }^{6}$ Ukraine-Russland Chronik (Ukraine-Russia Chronicle), available at https://gfbvblog.wordpress. com/tag/ukraine/ (accessed: 21 November 2020).

7 Quarteera: "Aktiv für Demokratie und Toleranz" (Quarteera: Active for Democracy and Tolerance), available at http://www.quarteera.de/blog/Aktiv-fuer-Demokratie-und-Toleranz (accessed: 3 October 2020). 
organisation seeks to provide practical information and foster a dialogue between project participants and the general public. The communication tool thus presents another example for developing the opportunities for intercultural understanding through civil society activism.

\section{Discussion and conclusion}

The analysis of challenges and opportunities for CSOs in Germany is a snapshot, reflecting the major trends in civil society development in 2016. The situation of CSOs in Germany is as diverse as the organisations that populate the arena of civil society in Germany. In comparison to other countries in Europe, which were also covered in the "Report on the State of Civil Society in the EU and Russia", the situation in Germany appears to be relatively favourable. From the online survey and the in-depth interviews, one can conclude that many representatives of German civil society evaluated the situation of their organisations as positive and stable. Whenever they mentioned problems or difficulties, these concerned more general trends in society, e.g. the impact of the refugee crisis or growth of populist movements. Concerning funding opportunities and institutional set-up, most German CSOs were relatively satisfied with the situation in Germany. However, many organisations noticed a growing competition on funding and media awareness among CSOs. Organisations have to invest a lot to create support for their work, a trend also observed by Evers and Zimmer (2010).

From a theoretical perspective, the concept of "shrinking spaces for civil society" thus appears to be somewhat one-sided. Although many German CSO representatives have mentioned several difficulties, some also reported about opportunities for organisational development. Some scholars describe this development as a "fragmentation of civil society" (Bode, 2014: p. 90). Overall, the organisations described themselves as actively shaping their environment. Intercultural communication and understanding emerges as an important activity for CSOs in Germany. Many organisations which participated in the survey and the interviews are active in the area of cultural and/or educational exchange with Eastern Europe and Russia. These organisations reported that the conflict in Ukraine and the increasing tensions between Russia and the EU have had a negative impact on the transnational activities of the organisations. For many CSOs, it has become more complicated to collaborate with partner organisations in Russia and Ukraine, as they need to protect their partner organisations from potential allegations.

An important quality of CSOs is their ability to develop understanding between different members of society. Many organisations have mentioned the possible role of civil society in creating bridges between societies in conflict, e.g. by providing information about human rights and interethnic relations in Eastern Europe, as can be seen in the information and communication projects of The Society for Threatened Peoples. Other CSOs deal with integration and intercultural understanding in Germany. CSOs, such as the German Youth Fire Service, have developed social programmes to integrate newcomers. With regard to intercultural communication, civil society can thus play and 
important role in strengthening integration and inclusion. Moreover, the LGTBQ+ organisation Quarteera demonstrates how civil society can use communication tools to provide social support and community building. The organisational solutions, developed by the selected three organisations, illustrate how civil society can foster social cohesion in a multicultural society.

\section{References}

Publications

Anheier, H. K., Lang, M., \& Toepler, S. (2019). Civil society in times of change: shrinking, changing and expanding spaces and the need for new regulatory approaches. Economics: The Open-Access, Open-Assessment E-Journal, 13(8), 1-27. http://dx.doi. org/10.5018/economics-ejournal.ja.2019-8.

Archambault, E., Priller, E., \& Zimmer, A. (2014). European civil societies compared: Typically German — typically French? Voluntas, 25, 514-537.

Bode, I. (2014). Wohlfahrtsstaatlichkeit und Dritter Sektor im Wandel: Die Fragmentierung eines historischen Zivilisationsprojekts. In A. Zimmer, \& R. Simsa (eds), Forschung zu Zivilgesellschaft, NPOs und Engagement. Quo vadis? (81-95). Springer VS.

Enquete-Kommission „Zukunft des Bürgerschaftlichen Engagements“ Deutscher Bundestag (2002): Bericht. Bürgerschaftliches Engagement: auf dem Weg in eine zukunftsfähige Bürgergesellschaft. Leske+Budrich.

Evers, A., \& Zimmer, A. (eds) (2010). Third Sector Organisations Facing Turbulent Environments. Sports, Culture and Social Services in Five European Countries. Nomos.

Hummel, S. (2019). Shrinking Space for Civil Society (SCS). Zugänge zu einem globalen Problem. Observatorium, 33. https://web.maecenata.eu/observatorium.

Koch-Baumgarten, S. (2014). Verbände zwischen Öffentlichkeit, Medien und Politik. Springer VS.

Olk, T., Klein, A., \& Harnuß, B. (eds) (2010). Engagementpolitik. Die Entwicklung der Zivilgesellschaft als politische Aufgabe. Springer VS.

Priemer, J., Labigne, A., \& Krimmer, H. (2015). Wie finanzieren sich zivilgesellschaftliche Organisationen in Deutschland? In Kooperation mit der Körber-Stiftung. ZiviZ.

Simonson, J., Vogel, C., \& Tesch-Römer, C. (eds) (2017). Freiwilliges Engagement in Deutschland - Der Deutsche Freiwilligensurvey 2014, Springer VS.

Zimmer, A. (2010). Third sector-government partnerships. In R. Taylor (ed.), Third sector research. Springer.

Zimmer, A., \& Priller, E. (2007). Gemeinnützige Organisationen im Gesellschaftlichen Wandel. $2^{\text {nd }}$ edition.VS Verlag für Sozialwissenschaften.

Zimmer, A., Priller, E., \& Anheier, H. (2013). Der Nonprofit-Sektor in Deutschland. In R. Simsa, M. Meyer, \& C. Badelt (eds), Handbuch der Nonprofit-Organisation. (15-36). $5^{\text {th }}$ edition. Schäffer-Poeschel. 
Zimmer, A., Rentsch, C., Pahl, B., \& Hoemke, P. (2016). National report Germany: Identifying external and internal barriers on third sector development, TSI National Report Series No. 6. Seventh Framework Programme (grant agreement 613034), European Union. Third Sector Impact.

\section{Internet resources}

Deutsche Jugendfeuerwehr, available at http://www.jugendfeuerwehr.de/ (accessed: 21 November 2020).

EU-Russia Civil Society Forum, https://eu-russia-csf.org/ (21 November 2020).

Deutscher Freiwilligensurvey (FWS), available at https://www.dza.de/forschung/fws.html (accessed: 21 November 2020).

Initiative Transparente Zivilgesellschaft, available at https://www.transparency.de/Initiative-Transparente-Zivilg.1612.0.html (accessed: 21 November 2020).

Quarteera: "Aktiv für Demokratie und Toleranz" (Quarteera: Active for Democracy and Tolerance), available at http://www.quarteera.de/blog/Aktiv-fuer-Demokratie-und-Toleranz (accessed: 21 November 2020).

Society for Threatened Peoples (Gesellschaft für bedrohte Völker), available at https:// gfbv.de/ (accessed: 21 November 2020).

Ukraine Chronik (Ukraine-Russia Chronicle), available at https://gfbvblog.wordpress.com/ tag/ukraine/ (accessed: 21 November 2020).

Wegweiser Bürgergesellschaft, available at http://www.buergergesellschaft.de/ (accessed: 21 November 2020).

Zivilgesellschaft in Zahlen, available at http:/www.ziviz.info/ (accessed: 21 November 2020).

Overview of interviews

Interview 1, managing director of Bundesnetzwerk Bürgerschaftliches Engagement [National Network for Civil Society], Berlin, 25 July 2016.

Interview 2, managing director of the German branch of Service Civil International, Bonn, 26 July 2016.

Interview 3, director of the Berlin office of the Gesellschaft für bedrohte Völker [The Society for Threatened Peoples], Berlin, 27 July 2016.

Interview 4, education officer at Deutsche Jugendfeuerwehr [German Young Firefighters], Berlin, 27 July 2016. 